\title{
"An extended model of the antecedents and consequences of consumer satisfaction for hospitality services"
}

\author{
EJM Manuscript \# 33/05
}

(First submitted January 2005)

(Second re-submission June 2006)

(Accepted, August 2006)

\section{Yuksel Ekinci, Philip L. Dawes and Graham R. Massey}

Yuksel Ekinci

Senior Lecturer in Hospitality Marketing

School of Management Studies

University of Surrey

Guildford, Surrey GU2 7XH

UNITED KINGDOM

Phone: 01483-686-376

Fax: 01483-689-511

Email: y.ekinci@surrey.ac.uk

Philip L. Dawes

Professor of Marketing

Wolverhampton Business School

University of Wolverhampton

Compton Rd West

Wolverhampton WV3 9DX

UNITED KINGDOM

Phone: +44-1902-323-700

Fax: +44-1902-323-755

Email: p.dawes@wlv.ac.uk

Graham R. Massey

Lecturer in Marketing

School of Marketing

University Technology, Sydney

PO Box 123

Broadway NSW 2007

AUSTRALIA

Phone: +612-9514-3480

Fax: +612-9514-3535

Email:graham.massey@uts.edu.au 


\section{Acknowledgement}

We would like to thank the two anonymous reviewers for their helpful comments on this paper. Moreover, we would like to thank Professor Bob O'Keefe for his comments on the earlier draft of this manuscript. 


\title{
An extended model of the antecedents and consequences of consumer satisfaction for hospitality services
}

\begin{abstract}
Purpose - 1. To examine the impact of self-congruence on consumer satisfaction with services. 2. To develop and test a conceptual model of the antecedents and consequences of consumer satisfaction in the hospitality industry.

Design/methodology/approach - Our conceptual framework consists of the following constructs: actual self-congruence, ideal self-congruence, desires congruence, service quality, consumers' overall attitude to a service firm, and intention to return. Moreover, we develop and test twelve hypotheses. Exploratory and confirmatory factor analysis were used to test the validity of the measures, while PLS was used in hypotheses testing. Data were collected from 185 consumers who had recently visited a restaurant or hotel.
\end{abstract}

Findings - Overall, we find strong support for eleven of the twelve hypotheses. More specifically, the findings reveal that ideal self-congruence and desires congruence have positive effects on consumer satisfaction. In contrast, we show that actual self-congruence is not related to consumer satisfaction. Moreover, we demonstrate that the two dimensions of service quality - physical quality and staff behaviour - have a positive impact on both desires congruence and consumer satisfaction. Importantly, consumer satisfaction is found to be a better indicator of the consumers' overall attitude to the service firm than service quality. Finally, the study confirms that consumer satisfaction mediates the relationship between the two service quality dimensions, ideal self-congruence, and intention to return.

Originality/value - Our study makes four important contributions. First, we advance satisfaction research by integrating self-concept theory into the postpurchase evaluation of services. Second, we examine the relationship between the multidimensional nature of service quality and consumer satisfaction by testing paths from two posited dimensions of service quality - physical quality and staff behaviour - to satisfaction. Third, we integrate the consumers' overall attitude to a service firm into existing models of satisfaction and test its impact on behavioural loyalty (intention to return). Finally, we contribute to the satisfaction research literature by testing the effect of service quality on desires congruence, and the effect of desires congruence on consumer satisfaction.

Keywords: self-congruence, desires congruence, service quality, comparison standards, consumer satisfaction, model testing, hospitality services.

Paper type: Research paper 


\section{Introduction}

Despite a long-term interest in the understanding of consumer satisfaction, its relationship with service quality and the consumers' overall attitude to a service firm is still unclear. Given that satisfaction is claimed to be theoretically distinct from service quality and the consumers' overall attitude to a service firm, it is surprising to find that little research has investigated this distinction. Though not fully addressing this shortcoming, Oliver (1980; 1997) argued that satisfaction is similar to the consumers' overall attitude to a service firm and mediates changes between attitudes formed at the prepurchasing and postpurchasing point. Accordingly, satisfaction is viewed as a transaction-specific evaluation of a service encounter which quickly decays, at the postpurchasing point, into the consumers' overall attitude to the service firm. In contrast, in the quality literature, Parasuraman et al. (1988) argued that service quality is universal, more enduring than satisfaction, and is therefore a better reflection of the consumers' overall attitude to the firm providing the service. As pointed out by several scholars, without definitional explication, true satisfaction will remain an elusive concept (Cronin et al., 2000; Fournier and Mick, 1999; Giese and Cote, 2000). Even though the literature is awash with theoretical arguments of this kind, we could not locate any research which has simultaneously examined how these three constructs are related to each other. Moreover, it seems important to examine how service quality, consumer satisfaction, and the consumers' overall attitude to a service firm affect intentions to return, because this outcome is both managerially and theoretically significant.

Besides investigating the effects of service quality, the consumers' overall attitude to a service firm, and consumer satisfaction on intentions to return, another key motivation was to incorporate self-concept (congruence) theory into existing models of satisfaction. Selfcongruence is defined as a good match between self-image and product image, and Sirgy (1982) argued that this construct will affect consumer intentions to return. Later, Belk (1988) broadened this view and stated that the symbolic aspects of goods and services - which are based on the consumers' self-concept - are also likely to affect other aspects of consumer choice behaviour such as brand preference and purchase intentions. However, its use in explaining consumer satisfaction is very limited.

Here, we expand our understanding of the usefulness of this theory in investigating consumer satisfaction. In short, we argue that the relationship between satisfaction and service quality captures the functional aspects of service consumption, whereas the relationship between self-congruence and satisfaction captures the symbolic aspects of service consumption. More specifically, functional consumption is utilitarian and aims to accomplish objective consumption goals which are related to the tangible benefits of conventional goods and services. By contrast, symbolic consumption is experiential and associated with intangible benefits which pertain more to the subjective characteristics of goods and services. Moreover, this form of consumption seeks emotional rewards such as feelings of excitement, fun, amusement, fantasy, sensory stimulation and enjoyment. Indeed, in many service consumption situations such as staying in a hotel or eating out at a restaurant, consumers may desire to obtain not only tangible benefits (e.g., thick carpets) but also symbolic benefits (e.g., cheerfulness, sociability, elegance) of service characteristics (Firat et al., 1995; Holbrook and Hirschman, 1982).

Our article makes four important contributions. First, we advance satisfaction research by integrating self-concept (congruence) theory (Sirgy, 1982). This theory has been widely applied to prepurchasing studies, mainly using the choice of goods, whereas we apply it to examine consumer satisfaction with services at the postpurchasing point. According to 
Zeithaml (1997), the distinction between goods and services is important because services, as compared to goods, contain more experience quality attributes, which can only be appreciated during or after consumption. Parallel to this, the perceptions of service attributes at the prepurchasing point are likely to be different from those at the postpurchasing point (Gardial et al., 1994). In our study of services, we also respond to Sirgy et al. (1997) who noted that research on the effects of self-congruence on consumer satisfaction and postpurchase behaviour is lacking.

Second, our model proposes paths from the two posited dimensions of service quality physical quality and staff behaviour - to satisfaction. Again, the distinction with respect to the dimensionality of service quality is important because previous researchers (e.g., Dabholkar et al., 2000) have been criticised on the grounds of their unidimensional view of service quality and use of a single-item measure to test how service quality and consumer satisfaction are related. In order to overcome this criticism, we conceptualise service quality as having two dimensions and employed two multi-item measures in the pilot study and then validated these dimensions in the major data collection phase. This distinction is important because past studies on service quality have usually failed to confirm the same dimensions when the scale was replicated. Also, we contribute to the debate on whether satisfaction or service quality is a better reflection of the consumers' attitude to a particular service firm (Oliver, 1997).

Third, we test paths from satisfaction and the consumers' overall attitude to a service firm, to intention to return. The empirical examination of these paths seems necessary because incorporating the consumers' attitudes into existing models of satisfaction explains one of the logical inconsistencies of the disconfirmation paradigm reported by early scholars (e.g., LaTour and Peat, 1979). Specifically, why do consumers continue to patronise the same service firm when service performance is below their expectations?

Finally, we contribute to the satisfaction research by testing the effect of service quality on desires congruence, and the effect of desires congruence on consumer satisfaction. An empirical examination of these paths is important because desires was recommended as a comparison standard for the evaluation of service quality and consumer satisfaction (e.g., Olshavsky and Spreng, 1989). However, past research has produced mixed results. For example, Westbrook and Reilly (1983) examined the effect of desires on consumer satisfaction through value percept-disparity, which they defined as the extent to which the product provided the desired features and performance characteristics. As the relationship between desires and satisfaction was not significant, he commented that the poor results might be due to measurement problems. In contrast, Spreng et al. (1996), who used an improved measurement procedure, found that desires congruence did have a strong impact on consumer satisfaction. Though both these studies tested the effect of desires congruence on consumer satisfaction, neither examined the effect of service quality on desires congruence.

To develop the context for this research, we now define and discuss the constructs in our conceptual framework. First, we examine consumer satisfaction which we model as a mediator variable. Next, we discuss the five antecedent variables to consumer satisfaction. These are: actual self-congruence, ideal self-congruence, desires congruence, and the two service quality dimensions of physical quality and staff behaviour. Finally, we examine two consequences of consumer satisfaction - the consumers' overall attitude to a service firm and intention to return. By modelling the constructs into these three categories, we broadly follow the approach adopted by Dabholkar et al. (2000). In short, the nature of our research is summarised in Figure 1. 


\section{[Take in Figure I]}

\section{Conceptual framework}

\section{Mediator: consumer satisfaction}

While the literature contains significant differences in the definition of satisfaction, there are at least two common formulations of satisfaction - one is transient (transaction-specific) while the other is overall (or cumulative) satisfaction. Transient satisfaction results from the evaluation of events and behaviours that occur during a single, discrete interaction at a service encounter. A key implication of this definition suggests that transient satisfaction should be captured immediately after each service interaction with the service encounter if a service firm provides multiple service encounters (e.g., satisfaction with reception services, restaurant services, and room service). For example, Danaher and Mattson (1994) measured satisfaction with services after each service encounter in hotels. On the other hand, overall satisfaction is viewed as a function of multiple transient satisfactions with services when perceived performance is compared to one or multiple subjective comparison standards. Thus, overall satisfaction is a postchoice evaluative judgement of a specific purchase occasion (Bitner and Hubbert, 1994). This conceptualisation is notable because behavioural researchers such as Oliver (1980) have developed a rich body of literature focusing on the antecedents (e.g., comparison standards) and consequences (e.g., behavioural intentions) of this type of satisfaction at the individual level (see Appendix A).

In addition, Anderson and Fornell (1994) emphasise that nearly all satisfaction research has adopted the overall satisfaction formulation because it is more fundamental and useful than transient satisfaction in predicting a consumer's behavioural intentions as well as a firm's past, present, and future business performance. Some authors (e.g., Tse et al., 1990) argue however that overall satisfaction may be based on many transient experiences with a product. But according to Oliver (1980), this kind of satisfaction is not always practical to measure and suitable for services for a number of reasons: (1) overall satisfaction quickly decays into the consumers' overall attitude to a service firm; (2) after a while, it is often very difficult for consumers to remember what their first satisfaction level was when they have had multiple experiences with a service firm; and (3) consumers do not always have the opportunity for multiple experiences with a particular service firm due to a lack of time, money, or accessibility.

More recently consumer satisfaction paradigm researchers have gone beyond these cognitively toned model formulations to recognise the affective nature of satisfaction (Giese and Cote, 2000). Perhaps, this viewpoint is best encapsulated in Oliver's (1997, p. 13) definition which states that: "Satisfaction is the consumer's fulfilment response. It is a judgement that a product or service feature, or the product or service itself, provided (or is providing) a pleasurable level of consumption-related fulfilment, including levels of under or overfulfilment".

Consistent with this notion, some studies have explored the roles and meaning of emotions in satisfaction. For example, Fournier and Mick's (1999) study revealed that beyond the cognitive (technical) nature of satisfaction, which emphasises different comparison standards and feedback from initial product performance, the emotional (artful) nature of satisfaction captures the defining tone of consumer satisfaction which may be specific to cultures, values and metaphors. Giese and Cote's study (2000), which involved thirteen focus group interviews with 135 adult consumers, confirmed the emotional characteristics of satisfaction. Nearly eighty percent of the respondents used affective responses to describe their dis/satisfaction with products. Further, sixty percent of the personal interviewees 
actually_changed the question term satisfaction to more affective terms. To some extent, these findings are similar to those of Oliver (1989) who identified five affective modes of satisfaction - contentment, pleasure, relief, novelty, and surprise. Although empirical examination of this paradigm has begun, a parsimonious structure for the underlying model has yet to emerge.

Here, we follow Oliver (1997) and view consumer satisfaction as a consumer's overall emotional response to the entire service experience for a single transaction at the postpurchasing point. This view seems most appropriate for the evaluation of services because they are: (a) intangible, and (b) a consumer's emotional response to services can best be captured after consumption.

\section{Antecedents: actual and ideal self-congruence}

The self-concept reflects how individuals evaluate themselves in an objective way in order to create a self-image about their identity. Moreover, cognitive psychologists view self-concept as a set of self-schemata which are organised cognitive structures in certain dominions of the self (Markus et al., 1985). As other schemata, these structures are activated when a person encounters a situation involving personally relevant information, and function as mnemonic devices in remembering external stimuli.

According to Sirgy (1982), consumers compare the external stimuli taken from product attributes against their self-concept. This idea was then extended to suggest that the greater the degree of congruence between self-concept and a product's image, the higher the probability of symbolic consumption. Thus, consumers tend to buy products that are similar to their self-concept and research indicates that self-congruence affects behaviour in different consumption situations such as house preference (Malhotra, 1988), purchasing of retail products (Sirgy and Samli, 1985), and developing positive attitudes to brands (Graeff, 1996; Hong and Zinkhan, 1995).

Importantly, even though the construct of the self-concept is widely accepted as being multidimensional, there is no consensus on how many dimensions are relevant. Some investigators argued that self-concept must be treated as having at least two dimensions - the actual self concept and ideal self concept. The former is the perception of oneself (Birdwell, 1966), whereas the latter is the image of oneself as one would like it to be (Landon, 1974). Other investigators have however gone beyond the duality of dimensions. For example, Sirgy (1982) referred to four dimensions of self: actual self-image, ideal-self image, social selfimage, and ideal social self-image.

Another issue in self-concept research relates to situational self-image which suggests that the choice of which self to express in consumption evaluation is influenced by the specific characteristics of a given situation (Schenk and Holman, 1980). Once an individual decides which image to express in a social situation, he/she looks for ways of expressing it. Hence, consumption of a service may be congruent with self-image in one situation but not in another. In addition, Landon (1974) stated that actual self-congruence may not be relevant to purchasing behaviour when it is perceived to be negative. His reasoning being that consumers do not want to superimpose their negative self-concept on product evaluations. In sum, the influence of self-congruence on consumer behaviour may differ across consumption situations.

Support for this contention is provided by the sparse literature which has examined the relationship between self-congruence and purchasing behaviour (e.g., Hong and Zinkhan, 1995). On the basis of this premise, it seems reasonable to posit that different types of self should be taken into account when investigating the relationships between self-congruence and consumer satisfaction. But in order to limit ourselves, we focus on actual and ideal self- 
concept for two reasons. First, these two types of self are the most frequently studied constructs. Second, the other self-concepts (e.g., social self) are highly correlated with the actual and ideal self-concepts. By limiting ourselves in this way, we respond to Sirgy's (1982) comment that the proliferation of the different types of self-concept has had a negative impact on the theoretical parsimony of the self-concept models. Consistent with prior research, we take the view that: (a) actual self-congruence relates to the extent that a service provider's image matches up with a person's actual self-image, and (b) ideal self-congruence refers to the extent that a service provider's image matches up with a person's ideal self-image.

\section{Antecedent: desires congruence}

The use of a comparison standard, such as values (e.g., desires) and expectations, is central to the evaluations of both service quality and consumer satisfaction (Woodruff et al., 1991). In our study, we focus on values (desires) for two reasons. First, employing values as a comparison standard is theoretically compelling because they are the centrepiece of human perception. According to Rokeach (1973), beliefs, attitudes and values are all organized together into a functionally integrated cognitive system. Within this system, beliefs represent the most basic element and may be considered as simple propositions. Moreover, a value is viewed as a single belief which guides actions and judgements across specific situations and beyond immediate goals to more ultimate end-states of existence.

Second, past research suggests that desires congruence can be a better predictor of satisfaction than the disconfirmation-of-expectations (e.g., Barbeau, 1985; Wirtz and Matilla, 2001). Although "expectations" are sometimes mixed with "desires" in the service quality literature, the two concepts are distinct (Spreng et al., 1996). Desires can be conceptualized at two levels of abstraction. At the higher level, desires are associated with consumer values or life goals. At the lower level, they are associated with consumer needs or product benefits that can be obtained from product attributes. Here, we focus on the higher level of abstraction and examine the effect of desires congruence on consumer satisfaction. Consistent with prior research (e.g., Wirtz and Matilla, 2001), we define desires congruence as the subjective assessment of the comparison between what is desired and what is received from the performance of the firms' goods and services.

Accordingly, we assessed desires congruence using a two-stage process. First, the overall service performance was compared against the respondents' desires (goals) to capture any discrepancy. Then, the intensity of this discrepancy was evaluated in terms of being "good" or "bad". Thus, our approach differs from the use of expectations as a comparison standard in three ways. First, service benefits were captured at the postpurchasing point as opposed to the prepurchasing point. This is because service benefits can best be understood at the postpurchasing point due to their intangibility. Second, the outcome of this evaluation was not obtained through the mathematically computed gap scoring that is common for assessing the discrepancy between performance and a comparison standard. Third, the intensity of a discrepancy was re-evaluated according to the consumers' value judgements. This operationalisation addresses the concerns of performance measurement when a product benefit is evaluated through a finite-ideal attribute which means that an increasing level of perceived performance leads to dissatisfaction (Teas, 1993).

Following Sirgy et al. (1997), we also distinguish between "self-congruence" and "desires congruence" even though both concepts seem to be very much alike in terms of the cognitive process which starts with evaluating attributes of a particular service against some reference. In self-congruence, the reference may be the actual self-concept (or ideal selfconcept) and the attributes are symbolic in nature. In desires congruence, the reference is the goals or desires while the service benefits are tangible, functional and performance-like. With 
this in mind, consumers can compare the perceived performance against their desires after considering their past experiences with similar services, brands, or perceived reference prices.

\section{Antecedent: service quality}

The recent literature suggests that service quality is the consumer's subjective assessment of service performance (Cronin and Taylor, 1992; Dabholkar et al., 2000). Although service quality is multidimensional, the outcome of research is inconclusive and there has been little agreement on the generic and specific service quality dimensions. This lack of agreement can largely be attributed to the fact that research in the area has been dominated by two schools of thought - the North American and Nordic - which have different assumptions regarding the service quality dimensions.

Initially, the North American School identified ten service quality dimensions which are best known as the SERVQUAL dimensions (Parasuraman et al., 1985). However, the original SERVQUAL dimensions were later found to be highly correlated and reduced to five dimensions: tangibles, assurance, reliability, empathy, and responsiveness (Parasuraman et al., 1988). Moreover, empirical studies found that more parsimonious models of service quality fitted the data better (e.g., Carmen, 1990; Parasuraman et al., 1991; 1994). For example, when the SERVQUAL scale was tested in the hotel and restaurant industry, a twodimensional model, as opposed to the five-dimensional model, was supported (Ekinci, 2001). Specifically, the tangible dimension was distinct but the four SERVQUAL dimensions assurance, reliability, empathy, and responsiveness - loaded onto the same factor which was called intangibles.

In contrast, scholars from the Nordic School (e.g., Lehtinen and Lehtinen, 1991) offered two and three dimensional models of service quality - physical quality, interaction quality, and output quality. In short, the Nordic School's view of service quality is mainly based on two dimensions, namely: (1) what customers get as a result of interaction with a service firm; and (2) how customers get services. Importantly, one stream of research found that a two or three dimensional service quality model offered by the Nordic School (e.g., Grönroos, 1984) was more valid when applied to multiple service industries (Brady and Cronin, 2001; Mels and Nel, 1997).

Consistent with the Nordic School and recent empirical findings, we identified two generic service quality dimensions - physical quality and staff behaviour. The physical evidence of service quality, which relates to the appearance and condition of the physical environment and facilities, has been strongly supported in many empirical studies (e.g., Parasuraman et al., 1988). Similarly, the behaviour of service employees, in terms of their competence, helpfulness, and responsiveness, has been an important element of service quality evaluation (e.g., Brady and Cronin, 2001; Ekinci, 2001; Mittal and Lasser, 1996).

Consequence: the consumers' overall attitude to the service firm

On the basis of prepurchase and postpurchase service evaluations, Oliver (1980) distinguished between two types of attitudes to services - antecedent and continuous. Further, he argued that a consumer's antecedent attitude may be different from their continuous attitude because satisfaction moderates the relationship between the two. Here, we just focus on the consumers' continuous attitude and define it in terms of the consumers' overall favourable feelings to a specific service firm. Importantly, the consumers' overall attitude to a service firm is a global image of that firm which can be developed before or after purchasing. We focussed on the continuous attitude, rather than on the antecedent attitude, because our study investigates consumer evaluations of services at the postpurchasing point. 
In line with Oliver's (1980) formulation, we mainly distinguish consumer satisfaction from the consumers' overall attitude to a service firm on the basis their antecedents. For example, satisfaction, which is more emotional and specific to a single transaction, requires usage experience. In contrast, the consumers' overall attitude, which can be both cognitive and affective, has image characteristics. Accordingly, the consumers' overall attitude to a service firm can be formed without usage experience through marketing communications or past experiences. Moreover, consumer satisfaction is generally viewed as one of the antecedents of the consumers' overall attitude to a firm at the postpurchasing point rather than the other way round.

\section{Consequence: intention to return}

According to a recent meta-analysis, only a few outcomes of satisfaction have been investigated in the satisfaction literature (Szymanski and Henard, 2001). These outcomes are complaining behaviour, word of mouth, and repurchase intentions. We chose the latter because past research suggests that behavioural loyalty is the most powerful outcome of consumer satisfaction. For example, Oliver (1997) proposes three components of satisfaction: cognitive, affective, and conative. The latter includes the use of repeat usage. Also, intention to return is highly correlated with other outcomes of satisfaction. For example Caruana (2002) investigated the relationship between customer satisfaction and service loyalty for retail banking services. In this research, the 12-item service loyalty scale, which included a variety of behavioural outcomes such as intention to re-use, intention to switch, and intention to recommend, loaded onto a single factor. Moreover, the items which had the highest factor loadings were related to intention to re-use behaviour, which is very similar to intention to return. Here, we define intention to return as a consumer's likelihood of re-purchasing the same service. And, this intention is developed as a result of a consumer's satisfaction with his/her last service encounter and overall attitude to the particular firm which provided the service.

\section{Research model}

Our research model was developed by integrating previous research on self-congruence (Sirgy, 1982), service quality (Brady and Cronin, 2001), and consumer satisfaction (Oliver, 1997). Figure 1 displays the relationships between the focal concstructs in our main model. In all cases, we posit that the antecedent variables will have a positive impact on consumer satisfaction. In addition, and based on the research of Wirtz and Matilla (2001), we specify paths from both dimensions of service quality to desires congruence ( $\mathrm{H} 3 \mathrm{c}$ and $\mathrm{H} 3 \mathrm{~d})$. And in line with Oliver's (1980) research, we posit a direct path from consumer satisfaction to the consumers' overall attitude to the service firm (H4a). Moreover, we postulate that satisfaction and the consumers' overall attitude to a service firm will have a positive impact on intention to return (H4b, H5). Finally, and consistent with the research of Oliver (1980) and Caruana (2002), we propose that consumer satisfaction mediates the impact of the five antecedents on intention to return (H6) and on the consumers' overall attitude to the service firm (H7). 


\section{Hypotheses development}

\section{Effects of actual and ideal self-congruence on consumer satisfaction}

According to the self-congruence model (Sirgy, 1982; Sirgy and Su, 2000), product stimuli involving images usually activate a self-schema which has the same images. And given the activation of a self-schema as a result of a product cue, the value placed on the product and its image attributes will be influenced by the evoked self-schema. Thus, consumers who perceive a product's image to be consistent with their actual self-image (self-congruence) are likely to feel motivated to consume that product. This is because the greater the self-congruence with a particular product, the greater the likelihood that this product will satisfy the need for selfconsistency and self-esteem. As explained by Hong and Zinkhan (1995), consumers can express their individualism and enhance their self-concept through this kind of symbolic consumption. For example, a customer who sees himself as being sophisticated (actual selfimage) and wishes to be more sophisticated (ideal self-image) is likely to be more satisfied when he has eaten in a stylish restaurant frequented by gourmets. This is because eating in such a restaurant will satisfy his need for self-consistency (by acting in a way which is congruent with his views of himself as being sophisticated) and his need for self-esteem (by acting in a way which is congruent with his ideal-image).

Research in the social psychology literature concerning the similarity of people in interpersonal relationships, has demonstrated that individuals are not only attracted but also tend to be affected by others who are similar to themselves in terms of characteristics such as demographics, culture, personality, attitudes, beliefs, and social class. Basically, similarity is emotionally rewarding because it provides socially-based reassurance and self-confirmation with respect to one's self-concept (e.g., Hendrick and Page, 1970; Moon, 2002). For example, in studies involving salespeople interacting with customers in a face-to-face environment, researchers have found that salespeople tend to be more successful and persuasive when they are able to convincingly imitate the characteristics of their customers (Woodside and Davenport, 1974). Moreover, Locke and Horowitz (1990) showed that the similarity of two peoples' mood is an important determinant of interactional satisfaction. What this research suggests is that individuals may have an affinity for interpersonal relationship styles which are congruent with their own personality style.

And consistent with Oliver's (1997) cognitive and affective theory of satisfaction, we posit that when consumers identify their actual personality in their consumption of a service (actual self-congruence), they fulfil the needs of self-consistency and self-esteem which evoke positive emotions and higher satisfaction. Therefore, we posit that:

H1a: Actual self-congruence will have a positive impact on consumer satisfaction in service encounters.

Generally speaking, past empirical studies have reported that the ideal rather than actual self-congruence has been more significant in explaining purchasing behaviour. For example, Malhotra (1988) found this to be the case with respect to the purchasing of houses. Moreover, a few studies concerning the consumers brand preference produced similar findings (Hamm and Cundiff, 1969; Hong and Zinkhan, 1995). Drawing on the above limited studies and the situational mode of self-concept, we posit that consumers who perceive a service firm's image to be similar to their ideal self image (ideal self-congruence) are more likely to feel higher satisfaction in service encounters. This is because the greater the ideal congruence with a particular service firm, the greater is the likelihood that a service from this firm will satisfy the need for self-esteem and self-consistency. Thus, we propose that: 
$H 1 b$ : Ideal self-congruence will have a positive impact on consumer satisfaction in service encounters.

\section{Effect of desires congruence on consumer satisfaction}

Satisfaction occurs when the benefits of services (or goods) meet or exceed consumer desires. And conversely, dissatisfaction results when the benefits fall short of consumer desires. This theoretical proposition is largely based on the means-end models which imply that benefits are linked to consumer values. As a result, consumers are likely to be more satisfied with services which fulfil their life goals and desires (Gutman, 1982; Olshavsky and Spreng, 1989). In short, this analysis suggests that consumer satisfaction is a cognitive and pleasurable emotional state resulting from the appraisal of a good or service leading to or achieving one's values. Conversely, consumer dissatisfaction refers to an unpleasurable emotional state resulting from an appraisal that an object, action, or condition blocks the achievement of one's values.

Spreng et al. (1996) found that desires congruence had a positive impact on attribute satisfaction, information satisfaction, and overall satisfaction. The latter finding concerning desires congruence and overall satisfaction was consistent with an earlier study by Spreng and Olshavsky (1993). Further support for this positive relationship was provided by Barbeau's study (1985) of desires congruence on student satisfaction with marketing courses. Finally, and more recently, Wirtz and Matilla (2001) showed that desires congruence contributed independently to satisfaction over and above the disconfirmation of expectations. Thus using these findings as our main justification, we expect that:

H2: Desires congruence will have a positive impact on consumer satisfaction in service encounters.

\section{Effects of service quality on consumer satisfaction}

Despite the ongoing debate on whether service quality is an antecedent or consequence of consumer satisfaction, we argue that the direction of the relationship should be from service quality to consumer satisfaction. This stance is based on the outcomes of recent conceptual and empirical studies. For example, Oliver (1993) suggested that overall service quality was an antecedent of consumer satisfaction and that both constructs should be positively associated with each other. Empirically, Dabholkar et al. (2000) found support for this proposition in the context of non-commercial organizations.

Here, and in contrast to Dabholkar et al. (2000), we focus on two separate dimensions of service quality - physical quality and staff behaviour - and posit that both will be positively related to consumer satisfaction. Though empirical research linking these constructs is sparse, specific support for the physical quality dimension and its positive relationship with consumer satisfaction is provided by Bitner (1992). In contrast, the performance of contact employees during interactions with customers has been the subject of considerable research in both sales and service settings (e.g., Bitner, 1990, 1992; Czepiel et al., 1985). According to this research, consumer evaluations are affected by the service employees' attitudes, behaviour, and skills. At the encounter level, the behaviour of contact employees is critical in satisfying customers' consumption needs or executing a discrete exchange. At the global level, research has found that customer-oriented employees who show empathy, understanding of the customer, interpersonal care, competent and trustworthy behaviour are able to develop a positive image and a long-term relationship with customers (e.g., van Dolen et al., 2004). Accordingly, it seems reasonable to assume that service employee behaviour (e.g., smiling, 
competence, helpfulness) are likely to be important in determining consumer satisfaction. Based on the above arguments and findings, we propose the following two hypotheses:

H3a: Favourable perceptions of the quality of the physical environment will have a positive impact on consumer satisfaction.

$H 3 b$ : Favourable perceptions of staff behaviour will have a positive impact on consumer satisfaction.

Effects of service quality on desires congruence

Wirtz and Matilla (2001) argue that the performance of a product has no meaning unless it is linked to human-value systems. Performance can become more meaningful in the context of evaluation, and this evaluation implicitly requires some comparison standards in order to make some reference when evaluating whether the performance is "good" or "bad". For example, friendliness may be considered as a desirable feature but if the employee is overfriendly, it may be evaluated negatively. Similarly, quick service may be appreciated in a fast-food restaurant but such service may not be evaluated as desirable in a fine dining restaurant where customers are likely to spend more time when eating their meals.

Prominent service quality scholars argue that if product performance is congruent with desires, it is likely to be considered satisfactory (e.g., Parasuraman et al., 1988; 1991). Moreover, Zeithaml et al. (1993) argue that perceived product performance should be congruent with the customers' desired service if it is considered to be satisfactory. More recently, Wirtz and Matilla (2001) showed that both objective and subjective performance measures have direct links with desires congruence and satisfaction. Therefore, we hypothesize that the evaluations of physical quality and staff behaviour will have positive affects on desires congruence. Hence, we propose that:

H3c: Favourable perceptions of the quality of the physical environment will have a positive impact on desires congruence.

H3d: Favourable perceptions of staff behaviour will have a positive impact on desires congruence.

Effect of consumer satisfaction on the consumers' overall attitude to the service firm

Here, we use Oliver's (1980) theory of satisfaction to justify the direction of our hypothesis (see Appendix A). According to Oliver's formulation of satisfaction, a consumer approaches a service encounter with an antecedent attitude which might have been formed in various ways such as past experiences, word of mouth communications or marketing promotions. Consistent with this view, satisfaction is a function of expectations (or a comparison standard) and the degree of the disconfirmation experience. Here, the expectations serve as a comparison standard and satisfaction is specific to a certain time and situation. After satisfaction emerges at the postpurchasing point, it quickly decays with the consumers' antecedent attitude to the service firm and the consumers' overall attitude to the service firm is formed. As a result, the direction and magnitude of satisfaction serves as an input to develop the consumers' overall attitude to the service firm. Therefore, and based on these theoretical discussions, it seems reasonable to posit that consumer satisfaction is likely to have a positive affect on the consumers' overall attitude to the service firm. Empirically, Olsen (2002) found that consumer satisfaction had a positive effect on relative attitudes which 
he defined in terms of how favourably consumers rate a particular brand or product in comparison to competing alternatives. Accordingly, we hypothesize:

H4a: Consumer satisfaction will have a positive impact on the consumers' overall attitude to a service firm.

\section{Effect of consumer satisfaction on intention to return}

Past research has extensively examined the relationship between satisfaction and behavioural intentions and the results suggest that satisfaction has a positive influence on intentions to return (e.g., Cronin et al., 2000; Dabholkar et al., 2000). Therefore, we propose that when consumers are more satisfied with a service firm, they will have greater intentions to return. Hence, we posit:

$H 4 b$ : Consumer satisfaction will have a positive impact on intention to return.

\section{Effects of the consumers' overall attitude to the service firm on intention to return}

We postulate that there is a positive relationship between the consumers' overall attitude to a service firm and their intention to return. Our reasoning being that when consumers make judgements about their intentions to return at the postpurchasing point, their evaluation is influenced by their satisfaction and overall attitude to the firm providing the service. For example, when a hotel visit is not as good as on previous occasions, consumers are likely to be more tolerant if they have a favourable overall attitude to the hotel. Here, overall satisfaction is an emotional evaluation of the entire service experience for this single transaction whereas the consumers' overall attitude is their global image of the entire service firm. Accordingly, our conceptualisation complements Oliver (1980), who specified a path from the consumers' overall attitude to a service firm to intention to return. The positive relationship between an attitude to an object and repeat purchasing is evidenced in previous studies (e.g., Szymanski and Heard, 2001). In short, we argue that when consumers have a more favourable attitude to a service firm, they are more likely to have intentions to return. Therefore, our next hypothesis is:

H5: When consumers have a more favourable attitude to the service firm, this will lead to increasing their intention to return.

\section{Mediating impact of consumer satisfaction on intention to return}

As discussed earlier, and consistent with Dabholkar et al. (2000), we posit that consumer satisfaction is likely to mediate the impact of the five antecedent variables on intention to return.

H6: Consumer satisfaction will mediate the impact of the five antecedent variables actual self-congruence, ideal congruence, desires congruence, physical quality and staff behaviour - on intention to return. 
Mediating impact of consumer satisfaction on the consumers' overall attitude to the service firm

Finally, and consistent with Oliver's (1980) theory of satisfaction and Caruana's (2002) empirical findings, we posit that consumer satisfaction is likely to mediate the impact of the five antecedent variables on the consumers' overall attitude to the service firm.

H7: Consumer satisfaction will mediate the impact of the five antecedent variables actual self-congruence, ideal self-congruence, desires congruence, physical quality and staff behaviour - on the consumers' overall attitude to the service firm.

\section{Method}

The research was organised in two stages. The first stage involved a pilot study to initially validate the scales while the second employed a large-scale survey to obtain the data for model testing.

\section{Pilot study}

The content of the initial questionnaire was pre-tested on 10 respondents. Then, the revised questionnaire was sent to 800 addresses which were randomly selected from a national mailing database in the UK. The only qualifying condition was that respondents must have stayed in a hotel within the last six months or eaten in a restaurant within the last four weeks. After 4 weeks, a total of 90 usable questionnaires were returned (net response rate $=11.2 \%$ ).

The purpose of this pilot study was to assess the reliability and validity of the scales. To do this, Cronbach's alpha statistic was used to assess the reliability of the scales while exploratory factor analysis with Varimax rotation was used to check the construct (discriminant and convergent) validity of the scales (Churchill, 1979). For example, the exploratory factor analysis supported the discriminant and convergent validity of the two service quality scales - physical quality and staff behaviour - because the nominated scale items loaded onto the two factors without cross-loadings and the loadings for each item were substantially high $(>.5)$. Moreover, the alpha coefficients for both scales were higher than the commonly accepted value of .70 .

Finally, after inspection of the returned questionnaires, we made some minor corrections to the wording and layout of the questionnaire.

\section{Large-scale survey: data collection and sample}

The main study, which was conducted in a university town in the south of England (population of 120,000), involved dropping 1000 questionnaires (500 for hotels and 500 for restaurants) at randomly selected addresses. Stamped-addressed envelopes were used to increase the response rate. Respondents were asked to make evaluations about either a restaurant or a hotel which they had used within the last 4 weeks. After 6 weeks, a total of 185 usable questionnaires were returned (18.5\%). Fifty seven per cent of the questionnaires were completed by restaurant customers and $43 \%$ by hotel customers. The sample was $57 \%$ female, $43 \%$ male and, in terms of age group, 5\% were between 16 and 24, 26\% were between 25 and $34,18 \%$ were 35 and 44 , and $51 \%$ were 45 years of age or above. The majority of respondents $(33 \%)$ reported that it was their first visit to the self-nominated hotel or restaurant. Moreover, 33\% had visited the same hotel/restaurant at least once, while $44 \%$ had visited more than twice. The majority of the respondents had stayed in the hotels for leisure purposes $(70 \%)$. Most restaurant visits were in the evening $(34 \%)$. 
We focused on hotels and restaurants because they are frequently purchased services and used by most consumers. Accordingly, almost all of the respondents in our sample should have been able to complete the questionnaire and relate their answers to a recent purchasing decision. However, for the purposes of data analysis, the two data sets were merged to form a sample size of 185 - which facilitates the use of a stronger statistical test of our model. Though we used no formal test of metric equivalence, we felt justified in merging the data sets. This is because the two services - hotels and restaurants - are key components of the hospitality service sector which means that they are likely to have many similarities.

\section{Measures}

The scales used to measure the eight constructs in Figure 1 are summarized in Appendix B. A brief discussion of each measure now follows.

Actual and ideal self-congruence. An ongoing debate relating to self-congruence measurement is whether to use the "absolute difference" or "the direct-score formula" (Sirgy and $\mathrm{Su}$ 2000). Until recently, the usual practice has been to employ the absolute difference formula which requires calculating the absolute difference score between the self-image and product-image (Sirgy and Ericksen, 1992). However, this method was severely criticised because of inflating the reliability scores, producing spurious correlations among the variables, and a mathematically computed gap score which may not reflect the respondents' true feelings (Peter et al., 1993). Therefore, we used the direct-score method which assesses the degree of congruence between self-image and product-image. A Likert-type scale was employed and, as shown in Appendix B, it included a number of statements based on a scenario-type direction (Sirgy and Su, 2000). Both actual and ideal self-congruence were measured by using a two-item, 5-point scale.

Desires congruence. To operationalise this construct, we based our procedure on the one developed by Spreng and Mackoy (1996). Accordingly, in terms of the goods and services received from the hotel (or restaurant), respondents were asked for their assessment of how big the difference was between what they desired and what they actually received. We employed a 7-point scale anchored, " 1 = exactly as I desired" and "7 = extremely different than I desired". And, at the midpoint, we used the label "somewhat different than I desired". Following this, the respondents were asked to indicate how good or bad this difference was. An 11-point scale was used where "-5" was labelled as "very bad," and "+5 as "very good". The mid-point of the scale "0" was labelled as "neither bad or good". In model testing, desires congruence was treated as a formative measure. Thus, desires congruence was operationalised by multiplying the two scales. This measure represents an overall belief regarding the degree to which the tangible benefits of services match the respondents' desires and their evaluation of this belief.

This operationalization addresses the issue regarding the measurement of congruence constructs that was identified by Teas (1993) who stated that "the P-E (performanceexpectations) measurement specification as expressed in this equation suggests that perceived quality (Qi) increases as P increasingly exceeds the ideal point" (p. 19). Further, he pointed out however, that if an attribute is a finite ideal-point attribute, where the higher performance is sometimes evaluated negatively, then the different score operationalizations are not valid. For example, assume a customer desires a level of an attribute of 5 on a 7point scale which indicates a moderate level of employee friendliness. If the customer receives a level of performance of 1 (not at all friendly), the Performance (P) - Desires (D) is 
$1-5=-4$. If the customer received a level of performance of 7 (an over friendly employee), the P-D formulation is $7-5=2$. Thus, both are evaluated negatively by the customer but the P-D model gives opposite results although the second case is evaluated negatively due to over friendly employee. In fact, this may be one of the reasons that Westbrook and Reilly's (1983) findings were not more supportive of the influence of values where the service evaluation might have involved combinations of finite ideal-point and vector attributes of which the higher performance is always evaluated positively. This method enables the consumer to assess the degree of discrepancy between his or her desires and the performance. The consumer can then rate whether this difference is good or bad. In the case of a vector attribute, a difference could be rated either positively or negatively. In our example, using a finite ideal-point attribute, either situation would be evaluated negatively.

Service quality. Several measurement scales (e.g., SERVQUAL) have been developed to capture service quality as a multidimensional construct. In the hospitality industry however, research by Ekinci (2001) suggests that service quality has just two dimensions - physical quality and staff behaviour. Accordingly, we employed Ekinci's (2001) measures of physical quality and staff behaviour. These measures employed 5-point Likert scales and as shown in Appendix B, four items relate to staff behaviour while three apply to physical quality. In addition, we measured overall service quality using a 7-point, single-item which was anchored by the terms "extremely low quality/extremely high quality". We did this in order to assess the criterion validity of the two service quality scales (Cronin and Taylor, 1992).

Consumers' overall attitude to the service firm. This construct was operationalised by asking each respondent to provide judgements of their overall feelings towards the service firm (hotel or restaurant). This procedure, which was based on the work of Maoi and Olson (1994), involved the use of a three-item, 7-point semantic differential scale anchored by "dislike/like", "positive/negative" and "worthless/valuable". And, as can be seen in Appendix B, the middle item was reverse scaled.

Consumer satisfaction. Based on the research of Spreng and Mackoy (1996), we assessed overall satisfaction by means of a two-item scale. When providing their judgements, respondents were asked: "Overall, how do you feel about the services of the hotel (or restaurant) you have received?" Following this question, respondents were asked to provide ratings on two 7-point scales anchored as "terrible/delighted" and "completely satisfied/completely dissatisfied".

Intention to return. In order to operationalise this construct, respondents were asked: "How likely is it that you would return to this hotel (or restaurant)? A 7-point scale was used anchored by "extremely unlikely/extremely likely" (Cronin and Taylor, 1992).

\section{Results}

\section{Partial least squares}

As our sample was relatively small $(\mathrm{n}=185)$, we did not conduct confirmatory factor analysis to validate our measurement models. This is because in such situations, there is the likelihood of nonconvergence and improper solutions (Gerbing and Anderson, 1988). Instead, partial least squares (PLS) was used to estimate both the measurement and structural models, specifically, PLS Graph Version 3 (Chin, 2001). This particular procedure was employed 
because: (1) its use does not require making assumptions about multivariate normality, (2) it is most appropriate when a model contains both formative and reflective indicators, and (3) when the primary concern is with the prediction of endogenous variables (Chin, 1998; Fornell and Bookstein, 1982a).

Because our model includes both formative and reflective measures our estimation scheme for the outer (measurement) models were of two types, Mode A for the reflective measures, and Mode B for the single formative measure. Further, our weighting scheme for the inner (structural) model was path weighting, because of the three weighting scheme options available (centroid, factor, and path weighting), path weighting is the only one which takes into account the directionality of the structural model. Hence, it is the most useful scheme for estimating models with hypothesised causal relations (Chin, 1998).

\section{Assessments of validity and reliability}

Convergent validity was established in two ways. First, the t-values from the PLS were examined for each item, and all were statistically significant at the $p<.001$ level (Anderson and Gerbing, 1988). Second, the average variance extracted (AVE) for each construct was calculated, and all exceeded .50. The AVE for actual self-congruence for example was .88, while that of ideal self-congruence was .93. See Table I below.

\section{[Take in Table I]}

It was particularly important that we establish discriminant validity between three key pairs of constructs: the two self-congruence dimensions (actual self-congruence and ideal self-congruence), the two service quality dimensions (physical quality and staff behaviour), and the endogenous variables of consumer satisfaction and the consumers' overall attitude to the service firm. Fifteen pairs of constructs were tested using Fornell and Larcker's (1981) criterion, and discriminant validity was established between all reflective multi-item measures. The AVEs for physical quality and staff behaviour for example were .62 and .69 respectively, while the squared correlation was .17. In addition, as shown in Table II, the square root of the average variance extracted for each reflective construct is greater than all corresponding correlations (Fornell and Bookstein, 1982b; Fornell and Larcker, 1981), indicating that each construct is more highly correlated with its measure, than with any of the other model constructs.

\section{[Take in Table II]}

As noted at the foot of Table I, all the measures are reflective with the exception of desires congruence (formative) and intention to return which is a single-item measure. Reliability analysis revealed that the composite reliabilities for all scales are .83 or more. A full description of the final measures is shown in Appendix B.

In order to establish the stability and significance of our parameter estimates, we computed the $\mathrm{t}$-values on the basis of 500 bootstrapping runs. The $\mathrm{R}^{2}$ for intention to return is .667 , suggesting that our model explains $66.7 \%$ of the variance in this endogenous variable. Similarly, the $\mathrm{R}^{2}$ for the consumers' overall attitude (.671) and consumer satisfaction (.669) are high. However, the result for desires congruence is lower (.304). In addition, we calculated the Goodness of Fit by multiplying the average communality of the constructs (.822) by the average $\mathrm{R}^{2}$ of the constructs $(.288)$, and then took the square root of this calculation (Tenenhaus et al., 2005). This yields a GoF of .49, which is acceptable because values for $\mathrm{R}^{2}$ of 0.5 are considered to be quite good. Moreover, values for blockwise average 
communalities greater than 0.6 are reasonable (ours is .822). Overall, these results suggest that our model has good explanatory power.

Descriptive results - key findings

As depicted in Table II, the mean of desires congruence is -.62 , which indicates that the tangible benefits of the service are below the desired level. With respect to service quality, the means of physical quality (3.84) and staff behaviour (3.58) - as measured on 5-point Likert scales - suggest that the respondents rated service quality to be moderately high. Moreover, the small standard deviations for both constructs (.60 and .75) show relatively little variance. And consistent with these positive results, the means of intention to return (5.17) and customer satisfaction (5.19) indicate that, on average, respondents were mostly satisfied and likely to return to the service firm. However, the relatively large standard deviations (intention to return $=1.86$; consumer satisfaction $=1.35$ ) indicate significant variations in the responses. As noted, both these constructs were assessed using 7-point scales.

Tests of hypotheses H1a to H5

In Table III, we report the beta coefficients and t-values for the first ten hypotheses. In short, we found support for nine hypotheses. As depicted, H1a was the only non-significant hypothesis. Accordingly, we rejected this hypothesis which posited that actual self-congruence is likely to have a positive effect on consumer satisfaction. However, we did find support for $\mathrm{H} 1 \mathrm{~b}(\beta=$ $.12, \mathrm{p}<.05)$ which suggests that ideal self-congruence is an antecedent of satisfaction. Similarly, we found support for $\mathrm{H} 2(\beta=.32, \mathrm{p}<.001)$ which posited that desires congruence should positively impact on consumer satisfaction.

\section{[Take in Table III]}

As expected, the two dimensions of service quality - physical quality and staff behaviour - had positive effects on consumer satisfaction. Therefore, we found support for $\mathrm{H} 3 \mathrm{a}(\beta=.26$, $\mathrm{p}<.001)$ and $\mathrm{H} 3 \mathrm{~b}(\beta=.36, \mathrm{p}<.001)$. Moreover, examination of the beta values suggests that staff behaviour has a stronger impact on consumer satisfaction than physical quality. Importantly, we also found good support for the two hypotheses, $\mathrm{H} 3 \mathrm{c}$ and $\mathrm{H} 3 \mathrm{~d}$, which posited that physical quality $(\beta=.24, \mathrm{p}<.001)$ and staff behaviour $(\beta=.41, \mathrm{p}<.001)$ would have positive effects on desires congruence.

Turning to the next three hypotheses, we found that consumer satisfaction had positive effects on both the consumers' overall attitude to the service firm $(\beta=.82, \mathrm{p}<.001)$ and intention to return $(\beta=.35, \mathrm{p}<.001)$. Accordingly, we found strong support for H4a and $\mathrm{H} 4 \mathrm{~b}$. And as expected for H5, we found that the consumers' overall attitude to the service firm had a positive impact on intention to return $(\beta=.51, \mathrm{p}<.001)$. Finally, inspection of the beta values suggests that the consumers' overall attitude to the service firm $(\beta=.51)$ has a stronger positive impact on intention to return than consumer satisfaction $(\beta=.35)$.

\section{Tests of hypotheses H6 and H7: the mediating impact of consumer satisfaction}

Our research model specifies that consumer satisfaction mediates the effects of five antecedents on the two outcome variables of intention to return and the consumers' overall attitude to the service firm. In order to formally test the two mediation hypotheses, we used Baron and Kenny's (1986) criteria to establish whether the conditions for mediation exist. First, we first ran two PLS models to determine that there is a relationship between the antecedents and our 
two outcome variables. As can be seen in Table III under "Mediation test stage 1: antecedents to outcome variables", all antecedents have a statistically significant relationship with the two dependent variables, with the single exception of actual self-congruence $\rightarrow$ consumers' overall attitude to the service firm. Therefore, Baron and Kenny's (1986) first condition is largely met.

Next, we ran a PLS model to establish that there is a relationship between the antecedents and the mediator. Again, all but one of the antecedents (i.e., actual self-congruence) were significantly related to the mediator variable, consumer satisfaction. Therefore, Baron and Kenny's (1986) second criterion is largely met. Their third condition is that the mediator must affect the outcome variable. Because we have two dependent variables, we ran two PLS models linking the antecedents to the dependent variables, whilst controlling for the effect of the mediator on the two outcome variables. The tests revealed that the mediator has a statistically significant effect on the two dependent variables, hence our tests reveal that the conditions exist for mediation.

Last, we needed to determine which paths were mediated, and whether that mediation was full or partial. We did this by running a PLS model in which the antecedents predict the mediator, and another in which the antecedents and the mediator predict the dependent variables. The path coefficients and standard errors from our PLS output were then used in Sobel (1982) tests to determine whether the mediating relationships in our research model are greater than zero and statistically significant. When the mediating effect is divided by its standard error, this yields a $\mathrm{z}$-score for that effect. If the $\mathrm{z}$ score is $\geq \pm 1.96$, the mediating effect is significant at the .05 level. Our Sobel (1982) tests reveal that consumer satisfaction mediates the effects of all but one of our five antecedents on our two outcome variables. The effect of staff behaviour on intention to return for example, is mediated by consumer satisfaction, $(\mathrm{z}=$ 4.04; $\mathrm{p}=.000$ ). Similar results were found for all of the other antecedents, although the effect of ideal self-congruence on both intention to return, and consumers' overall attitude to the service firm only approached statistical significance $(\mathrm{z}=1.87 ; \mathrm{p}=.061)$ and $(\mathrm{z}=1.92 ; \mathrm{p}=.054)$ respectively. However, we did consider these results close enough to significance to conclude that a mediating effect exists.

Our results reveal that consumer satisfaction failed to mediate the effects of actual selfcongruence on the two outcome variables, and their associated $\mathrm{z}$ statistics and significance levels were virtually identical $(\mathrm{z}=.49 ; \mathrm{p}=.621)$. An examination of the model testing results in Table III however, shows that the path coefficient linking actual self-congruence to the mediating variable - consumer satisfaction - was itself nearly zero, and non-significant $(\beta=$ $.03 ; \mathrm{t}=.53)$. Accordingly, the likelihood of a significant relationship being present in the next links of the causal model (i.e., consumer satisfaction to either consumers' overall attitude, or intention to return) is very low.

Last, we used PLS to determine whether the mediating effect of consumer satisfaction was full or partial. For full mediation, the direct paths from the antecedents to an outcome variable should be zero when the mediating variable is included in the path model (Baron and Kenny, 1986; Frazier, Tix, and Barron, 2004). Accordingly we ran two PLS models, each of which linked the five antecedents to the mediating variable, but also simultaneously to the outcome variable. The results show that none of the five paths from the antecedents to intention to return were zero, though the path from staff behaviour to intention to return was low, and nonsignificant $(\beta=.03 ; \mathrm{t}=0.50)$, and the path from ideal self-congruence to intention to return fell marginally short of the t-value of 1.64 required to achieve significance at the .05 level $(\beta=.11$; $t=1.64)$. Similarly, none of the direct paths from the five antecedents to consumers' overall attitude to the service firm were zero, though three of the six were not statistically significant. 
To sum up, these findings provide strong evidence for the mediating role of consumer satisfaction between its five antecedents and two consequences - the consumers' overall attitude to the service firm and intention to return.

\section{Discussion}

\section{Theoretical implications}

The key contribution of this study is that it provides a more comprehensive model of the antecedents and consequences of consumer satisfaction with services. This claim is based on the grounds that we found strong support for 11 of the 12 hypotheses in our model. Overall, the study findings indicate that: (a) consumer satisfaction has multiple antecedents; (b) ideal self-congruence is an antecedent of satisfaction; (c) service quality has two dimensions physical quality and staff behaviour - which have positive effects on satisfaction; (d) desires congruence is a significant determinant of satisfaction; (e) satisfaction is a better reflection of the consumers' overall attitude to a service firm as opposed to service quality; (f) both satisfaction and the consumers' overall attitude to a service firm have positive effects on intention to return; and (g) satisfaction mediates the relationships between its antecedents and consequences.

An important contribution of our research is that we show that the ideal self-concept is a determinant of consumer satisfaction in the context of service consumption. We believe that this finding is important because the posited relationship between these two constructs captures the symbolic aspects of service consumption. Actual self-congruence however was not found to be an antecedent of consumer satisfaction. In short, these two findings suggest that ideal self-congruence has more aspiration compared to actual self-congruence. Moreover, the ideal self is more emotionally charged compared to the actual self because it represents the consumers' desirable personality. As explained by Hong and Zinkhan (1995), consumers can seek to enhance their self-esteem through their consumption of luxury or publicly consumed products and these kinds of consumptions generate positive feelings. Therefore, the ideal self-congruence had a significant positive effect on satisfaction, and so captures the consumers' overall emotional response to a service experience. Hotels and restaurants can be viewed as examples of the consumption of luxury or publicly consumed products and therefore it seems reasonable to assume that the ideal self-concept is likely to be more relevant in such contexts. Moreover, the effect of ideal self-congruence on intention to return is fully mediated by satisfaction whereas the effect of actual self-congruence on intention to return is direct without involving satisfaction. Overall, these findings lend support to the views of Malhotra (1988) and Landon (1974) who argued that the effects of the self-concept on consumer behaviour are likely to vary according to consumption situations.

In addition, and as suggested by Cronin et al. (2000), the results indicate that service quality is a multidimensional and performance-like evaluation. As such, our findings support the external validity of the two service quality dimensions - physical quality and staff behaviour - which were originally recommended by Grönroos (1984). This is an important addition to the current models of service quality. Prior to this study, replication of the prominent service quality dimensions had been recognised as one of the issues in the service quality literature because the majority of the studies were unable to replicate the same generic dimensions when tested in a specific service firm.

One of our main contributions to the theory of satisfaction is that we provide empirical evidence for the debate on the relationship between consumer satisfaction, service quality, and the consumers' overall attitude to a service firm. Though the relationships between 
satisfaction and these two concepts have been theoretically discussed, they have not been examined simultaneously in any empirical studies. Here, we address this shortcoming, and consistent with Oliver $(1980,1992)$, we show that consumer satisfaction rather than service quality is a better reflection of the consumers' overall attitude to a service firm. In line with this view, the impacts of physical quality and staff behaviour on the consumers' overall attitude to a service firm were mediated by consumer satisfaction. As such, these findings also support those of Dabholkar et al. (2000) and indicate that service quality is an antecedent of satisfaction and closely related to specific multiple-factor evaluations of a service firm.

The consumers' overall attitude to a service firm and intention to return were found to be consequences of satisfaction. Furthermore, satisfaction and the consumers' overall attitude were found to be antecedents of intention to return. This is an important addition to the existing models of satisfaction because incorporating attitudes into existing models of satisfaction explains one of the logical inconsistencies of the disconfirmation paradigm which was reported by early scholars such as LaTour and Peat (1979). Thus, consumer satisfaction is not the only determinant of intention to return. And by the same token, the consumers' overall attitude to a service firm should be taken into account when predicting intention to return. As such, this finding partly supports Oliver's (1999) conceptual model regarding the relationship between satisfaction and consumer loyalty. Hence, satisfaction is essential for establishing behavioural loyalty (e.g., intention to return) but may become less important as loyalty is influenced by other means such as marketing communications and loyalty programs. And because consumers can develop their attitude to a service firm through other means, this suggests that additional factors can have a positive influence on intention to return beyond satisfaction. Also, it seems reasonable to argue that multiple dissatisfaction experiences with a service firm will negatively impact on the consumers' overall attitude to a service firm and intention to return in the long run.

A further contribution is that we found a significant relationship between desires congruence and consumer satisfaction with services at the postpurchasing point. In short, our results indicate that customers use their desires as a comparison standard for assessing satisfaction which is in line with the notion that the consumers' goals and product benefits are seen as one of the antecedents of consumer satisfaction (Spreng et al., 1996). Despite the fact that past researchers (e.g., Westbrook and Reilly, 1983) have recognised the importance of desires as a comparison standard in satisfaction research, the results have been mixed. Prior to this study, there was little evidence from field surveys to support this hypothesis in service consumption. As noted, the two main studies in this area employed experimental research designs (Spreng et al., 1996; Wirtz and Matilla, 2001).

Also, our study suggests that desires congruence and service quality are related but different constructs. Specifically, service quality relates to service performance while desires congruence applies to the entire tangible benefits which consumers want to obtain from goods and services. Thus, desires congruence is not limited to service quality evaluation or servicerelated benefits. For example, a convenient location can be a benefit but not an element of service quality. Alternatively, cleanliness can be an element of service quality but may not be the only benefit which business travellers wish to experience during their visit. A business traveller may be satisfied with the quality of a hotel's cleanliness but s/he may be more interested in how convenient the hotel location is. Thus our findings indicate that desires congruence serves as a comparison standard between service quality and consumer satisfaction when a service quality item is considered as a benefit. In addition to selfcongruence, desires congruence serves as another comparison standard for satisfaction. This finding suggests that consumers use multiple comparison standards for their satisfaction decision. Our study also shows that the impact of desires congruence on intention to return 
was mediated by satisfaction. Thus, our study findings suggest that service attributes or service benefits should also be satisfactory in order to have a significant impact on the consumers' intention to return.

Last, our findings demonstrate that consumer satisfaction mediates the effects of service quality on both the consumers' overall attitude towards the service firm and behavioural loyalty (i.e., intention to return). Our findings are therefore consistent with Caruana's (2002) study of service quality in banking services which found that customer satisfaction mediated the effects of service quality on service loyalty. However, our study extends Caruana's (2002) work by testing a model incorporating two underlying dimensions of service quality - staff behaviour and physical quality - and establishing that both are mediated by consumer satisfaction.

\section{Managerial implications}

Recognition of the importance of the antecedents of satisfaction has several practical implications. First, the concept of self-congruence implies that managers need to take into account their customers' ideal personality in order to influence customer satisfaction. Services should therefore be customized according to the consumers' self-image and their desires. For example, the interior of the service firm can be designed (e.g., using appropriate symbols, layouts) according to the customers' ideal personality in order to enhance symbolic consumption and develop emotional bonding between the service firm and its customers. Some service firms, such as hotels and mobile telephone companies, have shown that products can be customized according to customers' personality traits to stimulate higher satisfaction. For example, the promotion programme, "Wyndam by Request", introduced by Wyndam Hotels encourages customers to bring and display their personal items (e.g., photographs) in their rooms in order to increase higher self-congruence. As part of this programme, a hotel room is modified to improve its symbolic value. Upon a customer's request, the environment of the hotel room is changed to create a fantasy type environment. For instance, a hotel room is modified for a rock star's life style. Customers are being treated like a rock star which may represent their ideal self-image. As a result, they experience fun and entertainment. Similarly, mobile phones are customized by replaceable front covers and different ring tunes in line with various personality traits. Thus, consumers can express their individuality through this kind of symbolic consumption and obtain higher levels of satisfaction.

Second, this study suggests that service firms should use frontline employees effectively so as to form higher levels of self-congruence and positive customer experiences. Frontline employees should understand customers' ideal personality characteristics and desires. This could be put in to practice in a number of ways such as observing customer behaviour, knowing about the customers' interests (in particular having casual conversations with repeat customers) or using CRM technology. Then, serving styles could be modified accordingly. Thus, a frontline employee's interaction with an egocentric customer should be different from a customer who is outgoing and friendly. An egocentric customer may prefer his name to be remembered and have a formal conversation while an outgoing customer may wish to have a casual conversation at the service encounter. This would have specific implications on service firms' recruitment and in-house training. As such, front-line employees should be selected not only based on their technical skills (e.g., product knowledge) but also on their ability to recognise and fulfil the customers' symbolic needs. For instance the technical knowledge of a mortgage advisor would be essential to satisfy a customer's functional needs but the presentation of the service product through his/her body language, manner, and conversation 
would satisfy a customer's symbolic needs. The latter would establish an emotional connection and create a memorable service experience. Alternatively, front-line employees could be trained to understand and handle different customer personalities. In addition, those service firms that serve cross-cultural segments may employ the same nationality of service employees to arouse higher self-congruence, emotional bonding and consumer satisfaction.

Finally, the current satisfaction models seem to measure satisfaction by largely focusing on service quality dimensions. Though we acknowledge that service quality is important in assessing satisfaction, we contend that this narrow focus only captures the functional aspects of services and so inadequate measurement may be a problem. And due to this deficiency, we believe that current satisfaction surveys have already lost their credibility because their results provide little evidence for improving consumer satisfaction. In pragmatic terms, our research suggests that ideal self-congruence, desires congruence, service quality, and the consumers' overall attitude to a service firm should be taken into account in order to draw a more global picture of consumer satisfaction. In addition, the ideal self-congruence and desires congruence measures can be employed as a benchmark to locate and trace the levels of consumer satisfaction. This would provide better identification for true customer satisfaction measurement and its management.

\section{Limitations and future research}

Although our study makes important theoretical contributions to the understanding of the antecedents and consequences of consumer satisfaction with services, it has limitations. First, it is restricted to the hospitality service sector and so future researchers need to extend our research to other service sectors. This type of research may wish to examine if the impact of actual and ideal self-congruence on consumer satisfaction varies across different types of services such as those provided by supermarkets, medical practitioners, or banks. In line with this suggestion, research could further investigate whether the impact of self-congruence is

different across consumption situations such as when a customer stays in a particular hotel for business or leisure purposes.

In addition to physical quality and staff behaviour, future research may identify new dimensions of service quality which are specific to other service sectors and investigate their impact on satisfaction and the consumers' overall attitude to a service firm. Also, studies including variables such as complaining behaviour, service recovery strategies, and customer mood could expand the scope of our theoretical model. The following questions might direct the focus of future research. What is the impact of overall satisfaction on consumer complaining behaviour and a service firm's financial performance? Is satisfaction related to emotions such as trust, excitement, love, or disappointment? What is the relationship between transient satisfaction which is specific to each service encounter and overall satisfaction? Is encounter transient satisfaction influenced by service recovery? Does satisfaction accumulate over time when a consumer experiences multiple experiences with a service firm? What is the impact of satisfaction on the consumers' overall attitude to a service firm compared to other factors such as marketing communication, positive word-of-mouth, or personal needs?

The final limitation relates to our use of a non-probability sampling (convenience sample) procedure and a relatively small sample. Accordingly, future research should consider using a more comprehensive sampling design with a much larger sample. 


\title{
Appendix A \\ Oliver's (1980) Cognitive Model of Satisfaction
}

Oliver (1980) explains the cognitive relationship between satisfaction and a consumer's overall attitude to a service firm in terms of the following set of equations:

\author{
$\operatorname{ATTa}(\mathrm{t} 1)=\mathrm{f}($ expectations $)$ \\ intention $(\mathrm{t} 1)=\mathrm{f}(\operatorname{ATTs}(\mathrm{t} 1))$ \\ satisfaction $=\mathrm{f}($ expectations, disconfirmation $)$ \\ $\operatorname{ATTs}(\mathrm{t} 2)=\mathrm{f}(\operatorname{ATTTa}(\mathrm{t} 1)$, satisfaction $)$ \\ intention $(\mathrm{t} 2)=\mathrm{f}($ intention $(\mathrm{t} 1)$, satisfaction, $\operatorname{ATTs}(\mathrm{t} 2)$
}

ATTa $=$ consumers' overall attitude to the service firm before purchasing ATTs $=$ consumers' overall attitude to the service firm after purchasing 


\section{Appendix B \\ Measures}

\section{Actual self-congruence, ideal self-congruence (Sirgy and Sue, 2000)}

5-point Likert-type scale with "1" strongly disagree "5" strongly agree".

Please take a moment to think about the kind of person who typically visits the hotel (restaurant) you visited. Imagine this person in your mind and then describe this person using one or more personal adjectives such as organised, classy, poor, stylish, friendly, modern, traditional, popular or whatever other personal adjectives you can think of to describe the typical visitor of this hotel (restaurant).

Once you have done this indicate your agreement or disagreement with the following statements.

Actual self-congruence (composite reliability $=.94 ; A V E=.878$ )

The typical customer of this hotel reflects the type of person I am. $(.927)^{\mathrm{a}}$

The typical customer of this hotel is very much like me. (.946)

Ideal self-congruence (composite reliability $=.96 ; A V E=.926$ )

The typical customer of this hotel reflects the type of person I would like to be. (.960)

The typical customer of this hotel is very much like the person I admire. (.964)

\section{Desires congruence (Spreng et al., 1996).}

The following statements relate to the difference between what you desired to receive from the goods and services of this hotel and how well you think the same hotel's goods and services met your desires. The first question asks how big was the difference between what you desired, and what you actually received? Please put a circle around the number that best represents your opinion. Since a difference in desires can be either good or bad, the second question asks to rate your evaluation of this discrepancy. Put a circle around the number that expresses your evaluation.

Difference between what you desired and what you received

Exactly as I desired
Somewhat different than than I desired
How good or bad was this difference?

\begin{tabular}{llllllll|llllllllllll}
\hline 1 & 2 & 3 & 4 & 5 & 6 & 7 & -5 & -4 & -3 & -2 & -1 & 0 & 1 & 2 & 3 & 4 & 5
\end{tabular}


Service quality (Ekinci, 2001).

5-point Likert-type scale with "1" strongly disagree and "5" strongly agree.

Physical quality (composite reliability $=.83 ; \alpha=.70 ;$ AVE $=.619$ )

The décor was beautifully co-ordinated with great attention to detail. (.709)

The hotel (restaurant) was tidy. (.814)

The hotel (restaurant) provided a comfortable room. (.832)

Staff behaviour (composite reliability $=.90 ; \alpha=.85 ; A V E=.687$ )

Staff were helpful and friendly. (.808)

Staff seemed to anticipate what I wanted. (.805)

Staff listened to me. (.853)

Staff were talented and displayed a natural expertise. (.848)

Overall service quality

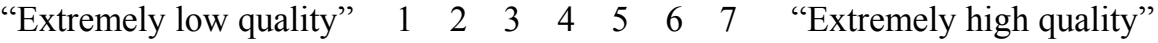

Consumers' overall attitude to the service firm (adapted from Maio and Olson, 1994).

(composite reliability $=.96 ; \alpha=.94 ; A V E=.890$ )

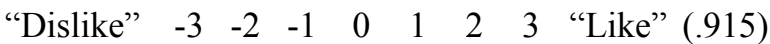

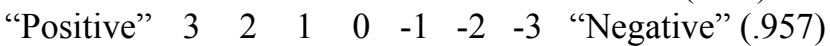

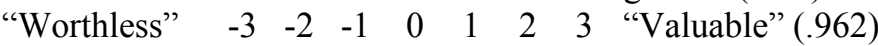

Overall consumer satisfaction (Spreng and Mackoy, 1996).

(composite reliability $=.98 ; \mathrm{AVE}=.955)$

$\begin{array}{cccccccccc}\text { "Terrible" } & 1 & 2 & 3 & 4 & 5 & 6 & 7 & \text { "Delighted" (.978) } \\ \begin{array}{c}\text { "Completely } \\ \text { satisfied" }\end{array} & 7 & 6 & 5 & 4 & 3 & 2 & 1 & \begin{array}{c}\text { "Completely } \\ \text { dissatisfied" }\end{array} & (.977)\end{array}$

Intention to return (Cronin and Taylor, 1992).

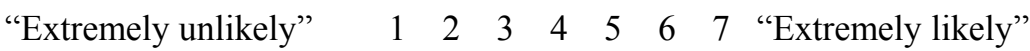

Note:

${ }^{a}$ Numerals in parentheses denote measurement model loadings for the reflective measures. 


\section{References}

Anderson, J.M. and Gerbing, D. (1988), "Structural equation modeling in practice: a review and recommended two-step approach", Psychological Bulletin, Vol. 103, May, pp. 411-23.

Anderson, E.W. and Fornell, C. (1994), "A Customer Satisfaction Research Prospectus", in Rust, R.T. and Oliver, R.L. (Eds), Service Quality: New Directions in Theory and Practice, Sage, Thousand Oaks, CA, pp. 241-68.

Barbeau, J.B. (1985), "Predictive and normative expectations in consumer satisfaction: a utilization of adaptation and comparison level in a unified framework", in Hunt, H.K. and Day, R. (Eds), Conceptual and Empirical Contributions to Consumer Satisfaction and Complaining Behavior, Indiana University School of Business, Bloomington, IN, pp. 27-32.

Baron, R.M. and Kenny, D.A. (1986), "The moderator-mediator variable distinction in social psychological research: conceptual, strategic, and statistical considerations", Journal of Personality and Social Psychology, Vol. 51, 1173-1182

Birdwell, A.E. (1968), "A study of the influence of image congruence on consumer choice", Journal of Business, 41, January, pp. 76-78.

Belk, R.W. (1988), "Possessions and the extended self", Journal of Consumer Research, Vol. 15, pp. 139-68.

Bitner, M.J. (1990), "Evaluating service encounters: the effects of physical surroundings on consumers and employees", Journal of Marketing, Vol. 54 No. 2, pp. 69-81.

Bitner, M.J. (1992), "Servicescapes: the impact of physical surrounding on consumers and employees", Journal of Marketing, Vol. 56, April, pp. 72-93.

Bitner, M.J. and Hubbert, A. (1994), "Encounter satisfaction versus overall satisfaction versus quality", in Rust, R.T. and Oliver, R.L. (Eds), Service Quality: New Directions in Theory and Practice, Sage, Thousand Oaks, CA, pp. 241-68.

Brady, M.K. and Cronin, J.J. Jr (2001), "Some new thoughts on conceptualizing perceived service quality: a hierarchical approach", Journal of Marketing, 65, July, pp. 34-9.

Carmen, J.M. (1990), "Consumer perceptions of service quality: an assessment of the SERVQUAL dimensions", Journal of Retailing, Vol. 66 No. 1, pp. 33-55.

Caruana, A. (2002), "Service loyalty: the effects of service quality and the mediating role of customer satisfaction", European Journal of Marketing, Vol. 36 No. 7/8, pp. 811-28.

Chin, W.W. (1998), “The partial least squares approach to structural equation modeling”, in Marcoulides, G.A. (Ed.), Modern Methods for Business Research, Lawrence Erlbaum Associates, Mahwah, NJ, pp. 295-336.

Chin, W.W. (2001), PLS Graph Version 3, Soft Modeling Inc.

Chon, K. (1992), "Self-image/destination image congruity", Annals of Tourism Research, Vol. 19 Issue 2, pp. 360-63.

Churchill, D. and Suprenant, C. (1982), "An investigation into the determinants of consumer satisfaction", Journal of Marketing Research, Vol. 19, November, pp. 491-504.

Churchill, G.A., Jr. (1979), "A paradigm for developing better measures of marketing constructs”, Journal of Marketing Research, Vol. 16 No. 1, pp. 64-73.

Cronin, J.J. Jr and Taylor, S.A. (1992), "SERVPERF versus SERVQUAL: reconciling performance-based and perception-minus-expectations measurement of service quality", Journal of Marketing, Vol. 58 No. 1, pp. 15-31.

Cronin, J.J. Jr, K. Brady, and Hult, G.T.M. (2000), "Assessing the effects of quality, value and consumer satisfaction on consumer behavioral intentions in service environments", Journal of Retailing, Vol. 76, No. 2, pp. 193-218. 
Czepiel, J.A., Solomon, M.R., Surprenant, C.F. and Gutman, E.G. (1985), "Service encounters: an overview", in Czepiel, J.A., Solomon, M.R. and Surprenant, C.F. (Eds), The Service Encounter: Managing Employee/Customer Interaction In Service Business, Lexington Books, Canada, pp. 3-15.

Dabholkar, P.A., Shepherd, C.D. and Thorpe, D.I. (2000), “A comprehensive framework for service quality: an investigation of critical conceptual and measurement issues through a longitudinal study", Journal of Retailing, Vol. 76 No. 2, pp. 139-73.

Danaher, P.J. and Mattson, J. (1994), "Cumulative service encounter satisfaction in the hotel conference process", International Journal of Service Industry Management, Vol. 5 No. 4, pp. 69-80.

Diamantopoulos, A. and Winklhofer, H.M. (2001), "Index construction with formative indicators: an alternative to scale development", Journal of Marketing Research, Vol. 38, May, pp. 269-77.

Ekinci, Y. (2001), "The validation of the generic service quality dimensions: an alternative approach", Journal of Retailing and Consumer Services, Vol. 8 No. 6, pp. 311-24.

Ekinci, Y., Riley, M., and Fife-Shaw, C. (1998), "Which school of thought? the dimensions of resort hotel quality", International Journal of Contemporary Hospitality Management, Vol. 10 No. 2/3, pp. 63-7.

Firat, A.F., Dhoakia, N. and Venkatesh, A. (1995), "Marketing in a postmodern world" European Journal of Marketing, Vol. 29 No. 1, pp. 40-56.

Fornell, C. and Bookstein, F.L. (1982a), "Two structural equations models: LISREL and PLS applied to consumer exit-voice theory", Journal of Marketing Research, Vol. 19, November, pp. 440-52.

Fornell, C. and Bookstein, F.L. (1982b), "A comparative analysis of two structural equation models: LISREL and PLS applied to market data", in Fornell, C., (Ed), A Second Generation of Multivariate Analysis, Vol. 1, Measurement and Evaluation, CBS Educational and Professional Publishing, Praeger Publishers, Westport, CT.

Fornell, C. and Larcker, D.F. (1981), "Evaluating structural equation models with unobservable variables and measurement error", Journal of Marketing Research, Vol. 18, February, pp. 39-50.

Fournier, S. and Mick, D.G. (1999), "Rediscovering satisfaction”, Journal of Marketing, Vol. 63, No. 4, pp. 5-23.

Frazier, P.A., Tix, A.P. and Barron, K.E. (2004), "Testing moderator and mediator effects in counselling psychology research", Journal of Counselling Psychology, Vol. 51 No.1, pp. 115-34.

Gardial, S.F. Clemons, D.S. Woodruff, R.B., Shumann, D.W. and Burns, M.J. (1994), "Comparing consumers' recall of prepurchase and postpurchase product evaluation experiences", Journal of Consumer Research, Vol. 24, March, pp. 548-60.

Giese, J.L. and J.A. Cote (2000), "Defining consumer satisfaction," Academy of Marketing Science Review, [Online] 00 (01): http://www.amsreview.org/amsrev/theory/giese 00$\underline{01 . h t m l}$

Gerbing, D.W. and Anderson, J.C. (1988), "An updated paradigm for scale development incorporating unidimensionality and its assessment", Journal of Marketing Research, Vol. 25, May, pp. 186-92.

Graeff, T.R. (1996), "Using promotional messages to manage the effects of brand and selfimage on brand evaluations", Journal of Consumer Marketing, Vol. 13 No. 3, pp. 418. 
Grönroos, C. (1984), “A service quality model and its marketing implications", European Journal of Marketing, Vol. 18 No. 4, pp. 36-44.

Gunderson, M.G., Heide, M. and H. Olsson, U.H. (1996), "Hotel guest satisfaction among business travellers: what are the important factors?", Cornell Hotel and Restaurant Administration Quarterly, Vol. 37 No. 2, pp. 72-81

Gutman, J. (1982), "A means-end chain model based on consumer categorisation processes", Journal of Marketing, Vol. 46, Spring, pp. 60-72.

Hamm, B.C. and Cundiff, E.W. (1969). "Self-actualisation and product perception", Journal of Marketing Research, Vol. 6, pp. 470-72.

Hendrick, C. and Page, H.A. (1970), "Self-esteem, attitude similarity, and attraction", Journal of Personality, Vol. 38, pp. 588-601.

Holbrook, M.B. and Hirschman, E.C. (1982), "The experiential aspects of consumption: consumer fantasies, feelings and fun", Journal of Consumer Research, Vol. 9, pp. $132-40$.

Hong, W.J. and Zinkhan, G.M. (1995), "Self-concept and advertising effectiveness: the influence of congruence, conspicuousness and response mode", Psychology and Marketing, Vol. 12 No. 1, pp. 53-77.

Landon, E.L. Jr (1974), "Self-concept, ideal self-concept, and consumer purchase intentions", Journal of Consumer Research, Vol. 1, pp. 44-51.

LaTour, S.A. and Peat, N.C. (1979), "Conceptual and methodological issues in consumer satisfaction research", in William, L.W. (Ed), Advances in Consumer Research, Association for Consumer Research, Ann Arbor, MI, pp. 431-37.

Lehtinen, U. and Lehtinen, J.P. (1991), “Two approaches to service quality dimensions", The Service Industries Journal, Vol. 11 No. 3, pp. 287-303.

Locke, K.D. and Horowitz, L.M. (1990), "Satisfaction in interpersonal interactions as a function of similarity in level of dysphoria", Journal of Personality and Social Psychology, Vol. 58, pp. 823-31.

Maio, G.R. and Olson, J.M. (1994), "Value-attitude-behaviour relations: the moderating role of attitude functions", British Journal of Social Psychology, Vol. 33, pp. 301-12.

Malhotra, N.K. (1988), "Self-concept and product choice: an integrated perspective", Journal of Economic Psychology, Vol. 9, pp. 1-28.

Markus, H., Smith, J. and Moreland, R.L. (1985), "Role of the self-concept in the perception of others", Journal of Personality and Social Psychology, Vol. 49 No. 6, pp. 14941512 .

Mels, G., Boshoff, C. and Nel, D. (1997), “The dimensions of service quality: the original European perspective revisited", The Service Industrial Journal, Vol. 17 No. 1, pp. 173-89.

Mittal, B. and Lasser, W.M. (1996), "The role of personalization in service encounters", Journal of Retailing, Vol. 72 No. 1, pp. 95-109.

Moon, Y. (2002), "Personalization and personality: some effects of customizing message style based on consumer personality", Journal of Consumer Psychology, Vol. 12 No. 4, pp. 313-26.

Oliver, R.L. (1980), "A cognitive model of the antecedents and consequences of satisfaction decisions", Journal of Marketing Research, Vol. 17 No. 4, pp. 460-69.

Oliver, R.L. (1989), "Processing of the satisfaction response in consumption: a suggested framework and research propositions", Journal of Consumer Satisfaction, Dissatisfaction and Complaining Behaviour, No.2, pp. 1-16. 
Oliver, R.L. (1993), "A conceptual model of service quality and service satisfaction: compatible goals, different concepts", Advances in Service Marketing and Management, Vol. 2, pp. 65-85.

Oliver, R.L. (1997), Satisfaction: A Behavioral Perspective on the Consumer, McGraw-Hill, New York.

Olshavsky, R.W. and Spreng, R.A. (1989), "A desires standard model of consumer satisfaction", Journal of Consumer Satisfaction Dissatisfaction and Complaining Behavior, Vol. 2, pp. 49-54.

Olsen, S.O. (2002), "Comparative evaluation and the relationship between quality, satisfaction, and repurchase loyalty", Journal of Academy of Marketing Science, Vol. 30 No. 2, pp. 240-49.

Parasuraman, A., Zeithaml, V.A. and Berry, L.L. (1985), "A conceptual model of service quality and its implications for future research", Journal of Marketing, Vol. 49, Fall, pp. 41-50.

Parasuraman, A., Zeithaml, V.A. and Berry, L.L. (1988), "SERVQUAL a multiple-item scale for measuring consumer perceptions of service quality", Journal of Retailing, Vol. 64, pp. 13-40.

Parasuraman, A., Zeithaml, V.A. and Berry, L.L. (1991), "Refinement and reassessment of the SERVQUAL scale”, Journal of Retailing, Vol. 67, Winter, pp. 420-50.

Parasuraman, A., Zeithaml, V.A. and Berry, L.L. (1994), "Alternative scales for measuring service quality: a comparative assessment based on psychometric and diagnostic criteria", Journal of Retailing, Vol. 70 No. 3, pp. 193-99.

Peter, J.P., Churchill, G.A. and Brown, T.J. (1993), "Cautions in the use of difference scores in consumer research", Journal of Consumer Research, Vol. 19 No. 4, pp. 655-62.

Reeves, C.A. and Bednar, D.A. (1994), "Defining quality: alternatives and implications", Academy of Management Review, Vol. 19 No. 3, pp. 419-45.

Rokeach, M. (1973), The Nature of Human Values, The Free Press, New York.

Saleh, F. and Ryan, C. (1991), "Analyzing service quality in the hospitality industry using the SERVQUAL model”, The Service Industries Journal, Vol. 11 No. 3, pp. 324-43.

Schenk, C.T and Holman, R.H. (1980), "A sociological approach to brand choice: the concept of situational self-image", in Olson, J. (Ed.), Advances in Consumer Research, Vol. 7, Association for Consumer Research, Ann Arbor, MI, pp. 610-14.

Sirgy, M.J. (1982), "Self-concept in consumer behavior: a critical review," Journal of Consumer Research, Vol. 9, No. 3, pp. 287-300.

Sirgy, M.J. and Samli, A.C. (1985), "A path analytic model of store loyalty involving selfconcept, store image, geographic loyalty, and socio-economic status", Journal of the Academy of Marketing Science, Vol. 13, pp. 265-91.

Sirgy, M.J. and Ericksen, M.K. (1992), 'Employed females' clothing preference, self-image congruence, and career anchorage", Journal of Applied Social Psychology, Vol. 22 No. 5, pp. 408-22.

Sirgy, M.J., Grewal, D., Mangleburg, T.F., Park, J., Chon, K., Claiborne, C.B., Johar, J.S. and Berkman, H. (1997), "Assessing the predictive validity of two methods of measuring self-image congruence”, Journal of Academy of Marketing Science, Vol. 25 No. 3, pp. 229-41.

Sirgy, M.J. and Su, C. (2000), "Destination image, self-congruity, and travel behavior: toward an integrative model”, Journal of Travel Research, Vol. 38, May, pp. 340-52. 
Sobel, M.E. (1982), "Asymptotic confidence intervals for indirect effects in structural equation models", in Leinhardt, S. (Ed), Sociological Methodology, American Sociological Association, Washington: DC, pp. 290-312.

Spreng, R.A. and Olshavsky, R.W. (1993), "A desires congruency model of consumer satisfaction", Journal of the Academy of Marketing Science, Vol. 21, Summer, pp. 169-77.

Spreng, R.A. and Mackoy, R.D. (1996), "An empirical examination of a model of perceived service quality and satisfaction”, Journal of Retailing, Vol. 72 No. 2, pp. 201-14.

Spreng, R.A, MacKenzie, S.B. and Olshavsky, R.W. (1996), "A re-examination of the determinants of consumer satisfaction”, Journal of Marketing, Vol. 60 No. 2, pp. 1532 .

Szymanski, D.M. and Henard, D.H. (2001), "Consumer satisfaction: a meta-analysis of the empirical evidence", Journal of the Academy of Marketing Science, Vol. 29 No. 1, pp. 16-35.

Teas, R.K. (1993), "Expectations, performance evaluation, and consumers' perceptions of quality", Journal of Marketing, Vol. 57, October, pp. 18-34.

Tenenhaus, M., Vinzi, V.E., Chatelin, Y-M. and Lauro, C. (2005), "PLS path modelling", Computational Statistics and Data Analysis, Vol. 48, pp. 159-205.

Tse, D.K., Nicosia, F.M. and Wilton, P.C. (1990), "Consumer satisfaction as a process", Psychology and Marketing, Vol. 7 No. 3, pp. 177-93.

van Dolen, W., de Ruyter, K. and Lemmink, J. (2004), “An empirical assessment of the influence of customer emotions and contact employee performance on encounter and relationship satisfaction", Journal of Business Research, Vol. 54 No. 4, pp. 437-44.

Westbrook, R.A. and Reilly, M.D. (1983), "Value-precept disparity: an alternative to the disconfirmation of expectations theory of consumer satisfaction", in Bagozzi, R.P. and Tybout, A.M. (Eds), Advances in Consumer Research, Association for Consumer Research, Ann Arbor, MI, pp. 256-61.

Wirtz, J. and Matilla, A. (2001), "Exploring the role of alternative perceived performance measures and needs-congruency in the consumer satisfaction process", Journal of Consumer Psychology, Vol. 11 No. 3, pp. 181-92.

Woodruff, R.B., Clemons, S.D., Schumann, D.W., Gardial, S.F. and Burns, M.J. (1991), "The standard issue in cs/d research: a historical perspective", Journal of Consumer Satisfaction, Dissatisfaction and Complaining Behavior, Vol. 4, pp. 103-09.

Woodside, A.G. and Davenport, W. Jr. (1974), "The effect of salesman similarity and expertise on consumer purchasing behavior," Journal of Marketing Research, Vol. 11, May, pp. 198-202.

Zeithaml, V.A. (1997), "How consumer evaluation processes differ between goods and services", in M. Gabbott and G. Hogg (Eds.), Contemporary Services Marketing Management: A Reader, The Dryden Press, London, pp. 34-43.

Zeithaml, V.A., Berry, L.L. and Parasuraman, A. (1993), "The nature and determinants of customer expectations of service", Journal of Academy of Marketing Science, Vol. 24 No. 1, pp. 1-12.

Zeithaml, V.A., Berry, L.L. and Parasuraman, A. (1996), "The behavioral consequences of service quality", Journal of Marketing, Vol. 60, April, pp. 31-6. 
Figure 1.

Research Model

Antecedents

Mediating variable

Consequences

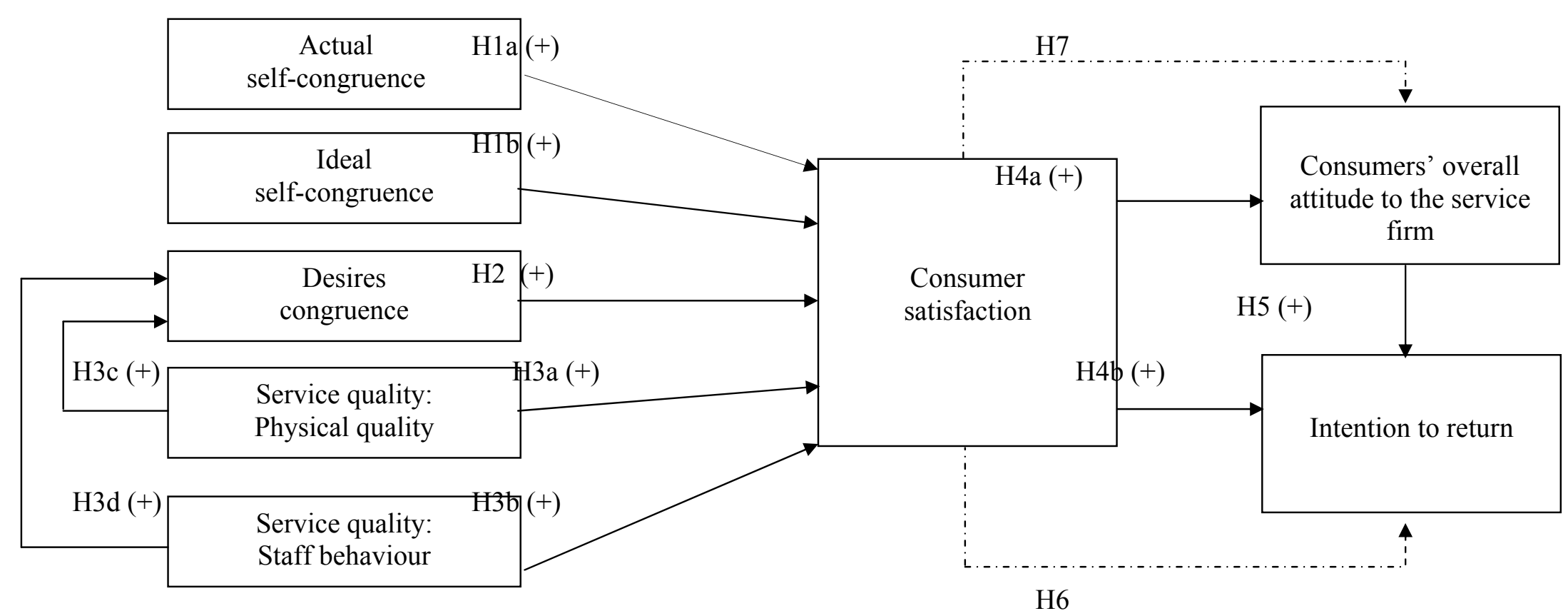


Table 1.

Assessment of measurement ${ }^{\mathrm{a}}$

\begin{tabular}{|c|c|c|c|c|c|}
\hline Construct & Indicator $^{b}$ & $\begin{array}{c}\text { Standardized } \\
\text { factor } \\
\text { loadings }\end{array}$ & t-statistic & $\begin{array}{l}\text { Composite } \\
\text { reliability }\end{array}$ & $\begin{array}{l}\text { Average } \\
\text { variance } \\
\text { extracted }\end{array}$ \\
\hline Actual self-congruence & $\begin{array}{l}1 \\
2\end{array}$ & $\begin{array}{l}.927 \\
.946\end{array}$ & $\begin{array}{l}35.778^{* * *} \\
58.089^{* * *}\end{array}$ & .94 & .88 \\
\hline Ideal self-congruence & $\begin{array}{l}1 \\
2\end{array}$ & $\begin{array}{l}.961 \\
.964\end{array}$ & $\begin{array}{l}78.837 * * * \\
84.794 * * *\end{array}$ & .96 & .93 \\
\hline Service quality: physical quality & $\begin{array}{l}1 \\
2 \\
3\end{array}$ & $\begin{array}{l}.712 \\
.810 \\
.835\end{array}$ & $\begin{array}{l}11.820 * * * \\
22.904 * * * \\
22.550 * * *\end{array}$ & .83 & .62 \\
\hline Service quality: staff behaviour & $\begin{array}{l}1 \\
2 \\
3 \\
4\end{array}$ & $\begin{array}{l}.809 \\
.807 \\
.851 \\
.847\end{array}$ & $\begin{array}{l}27.133^{* * *} \\
30.521^{* * *} \\
39.213^{* * *} \\
27.835^{* * *}\end{array}$ & .90 & .69 \\
\hline $\begin{array}{l}\text { Consumers' overall attitude to } \\
\text { the service firm }\end{array}$ & $\begin{array}{l}1 \\
2 \\
3\end{array}$ & $\begin{array}{l}.915 \\
.957 \\
.962\end{array}$ & $\begin{array}{l}36.770 * * * \\
107.204 * * * \\
111.722 * * *\end{array}$ & .96 & .89 \\
\hline Consumer satisfaction & $\begin{array}{l}1 \\
2 \\
\end{array}$ & $\begin{array}{l}.978 \\
.977 \\
\end{array}$ & $\begin{array}{l}233.425 * * * \\
201.052 * * * \\
\end{array}$ & .98 & .96 \\
\hline
\end{tabular}

a Because desires congruence is a formative measure and intention to return is a single-item measure, they are not included.

$\mathrm{b}$ The indicator number reflects the order of the indicators as described in the Appendix *** significant at the .001 level 


\section{Table II.}

Means, standard deviations and correlations

\begin{tabular}{|c|c|c|c|c|c|c|c|c|c|c|}
\hline Variable & $\begin{array}{l}\text { Scale } \\
\text { mean }\end{array}$ & S.D. & 1 & 2 & 3 & 4 & 5 & 6 & 7 & 8 \\
\hline 1. Actual self-congruence & 3.82 & 1.39 & .94 & & & & & & & \\
\hline 2. Ideal self-congruence & 3.21 & 1.62 & $.60 * *$ & .96 & & & & & & \\
\hline 3. Desires congruence & -0.62 & 10.17 & $.22 *$ & $.21^{*}$ & N.A. ${ }^{a}$ & & & & & \\
\hline $\begin{array}{l}\text { 4. Service quality: } \\
\text { physical quality }\end{array}$ & 3.84 & 0.60 & $.23^{*}$ & $.30^{* *}$ & $.38 * *$ & .79 & & & & \\
\hline $\begin{array}{l}\text { 5. Service quality: } \\
\text { Staff behaviour }\end{array}$ & 3.58 & 0.75 & $.28 * *$ & $.33 * *$ & $.50 * *$ & $.41^{* *}$ & .83 & & & \\
\hline $\begin{array}{l}\text { 6. Consumers' overall attitude } \\
\text { to the service firm }\end{array}$ & 1.64 & 1.08 & $.37 * *$ & $.41 * *$ & $.62 * *$ & $.55^{* *}$ & $.60 * *$ & .94 & & \\
\hline 7. Intention to return & 5.19 & 1.86 & $.42 * *$ & $.44 * *$ & $.60 * *$ & $.52 * *$ & $.56^{* *}$ & $.79 * *$ & N.A. ${ }^{b}$ & \\
\hline 8. Consumer satisfaction & 5.17 & 1.35 & $.33^{* *}$ & $.39 * *$ & $.61 * *$ & $.55^{* *}$ & $.64 * *$ & $.75^{* *}$ & $.74 * *$ & .98 \\
\hline
\end{tabular}

\section{Notes: * significant at the 0.05 level $* *$ significant at the 0.01 level (two-tailed tests).}

Numbers shown in boldface denote the square root of the average variance extracted (for reflective constructs only).

${ }^{a}$ Construct is a formative measure and so the square root of the average variance extracted is not calculated.

${ }^{\mathrm{b}}$ Single-item measure. 
Table III.

Results of hypotheses testing and tests of mediation using PLS

\begin{tabular}{|c|c|c|c|c|c|}
\hline \multirow[b]{2}{*}{ Hypothesis } & \multirow[b]{2}{*}{ Relationship } & \multicolumn{2}{|c|}{ Research model } & \multicolumn{2}{|c|}{ Mediation tests } \\
\hline & & Beta & t-value & Beta & t-value \\
\hline H1a & Actual self-congruence $\rightarrow$ consumer satisfaction & 0.03 & 0.53 & & \\
\hline $\mathrm{H} 1 \mathrm{~b}$ & Ideal self-congruence $\rightarrow$ consumer satisfaction & 0.12 & $2.11 *$ & & \\
\hline $\mathrm{H} 2$ & Desires congruence $\rightarrow$ consumer satisfaction & 0.32 & $4.77 * * *$ & & \\
\hline $\mathrm{H} 3 \mathrm{a}$ & Service quality: physical quality $\rightarrow$ consumer satisfaction & 0.26 & $4.60 * * *$ & & \\
\hline $\mathrm{H} 3 \mathrm{~b}$ & Service quality: staff behaviour $\rightarrow$ consumer satisfaction & 0.36 & $6.46^{* * *}$ & & \\
\hline $\mathrm{H} 3 \mathrm{c}$ & Service quality: physical quality $\rightarrow$ desires congruence & 0.24 & $3.48 * * *$ & & \\
\hline $\mathrm{H} 3 \mathrm{~d}$ & Service quality: staff behaviour $\rightarrow$ desires congruence & 0.41 & $7.19 * * *$ & & \\
\hline $\mathrm{H} 4 \mathrm{a}$ & Consumer satisfaction $\rightarrow$ consumers' overall attitude to the service firm & 0.82 & $24.96 * * *$ & & \\
\hline $\mathrm{H} 4 \mathrm{~b}$ & Consumer satisfaction $\rightarrow$ intention to return & 0.35 & $3.79 * * *$ & & \\
\hline H5 & Consumers' overall attitude to the service firm $\rightarrow$ intention to return & 0.51 & $5.64 * * *$ & & \\
\hline \multirow[t]{11}{*}{ H6, H7 } & Mediation test stage 1: antecedents to outcome variables & & & & \\
\hline & Actual self-congruence $\rightarrow$ intention to return & & & 0.12 & $1.86^{*}$ \\
\hline & Ideal self-congruence $\rightarrow$ intention to return & & & 0.16 & $2.35 * *$ \\
\hline & Desires congruence $\rightarrow$ intention to return & & & 0.32 & $4.64 * * *$ \\
\hline & Service quality: physical quality $\rightarrow$ intention to return & & & 0.24 & $4.54 * * *$ \\
\hline & Service quality: staff behaviour $\rightarrow$ intention to return & & & 0.21 & $3.31 * * *$ \\
\hline & Actual self-congruence $\rightarrow$ consumers' overall attitude to the service firm & & & 0.04 & 0.62 \\
\hline & Ideal self-congruence $\rightarrow$ consumers' overall attitude to the service firm & & & 0.14 & $2.07 *$ \\
\hline & Desires congruence $\rightarrow$ consumers' overall attitude to the service firm & & & 0.38 & $5.79 * * *$ \\
\hline & Service quality: physical quality $\rightarrow$ consumers' overall attitude to the service firm & & & 0.28 & $5.46 * * *$ \\
\hline & Service quality: staff behaviour $\rightarrow$ consumers' overall attitude to the service firm & & & 0.24 & $3.78 * * *$ \\
\hline \multirow[t]{6}{*}{ H6, H7 } & Mediation test stage 2: antecedents to mediator variable & & & & \\
\hline & Actual self-congruence $\rightarrow$ consumer satisfaction & & & .03 & 0.49 \\
\hline & Ideal self-congruence $\rightarrow$ consumer satisfaction & & & .12 & $2.00 *$ \\
\hline & Desires congruence $\rightarrow$ consumers satisfaction & & & .33 & $4.91 * * *$ \\
\hline & Service quality: physical quality $\rightarrow$ consumer satisfaction & & & .26 & $4.50 * * *$ \\
\hline & Service quality: staff behaviour $\rightarrow$ consumer satisfaction & & & .36 & $6.40 * * *$ \\
\hline \multirow[t]{3}{*}{ H6, H7 } & Mediation test stage 3: mediator variable to outcome variables & & & & \\
\hline & Consumer satisfaction $\rightarrow$ intention to return & & & .50 & $5.21 * * *$ \\
\hline & Consumer satisfaction $\rightarrow$ consumers' overall attitude to the service firm & & & .52 & $7.01 * * *$ \\
\hline
\end{tabular}

Note: ${ }^{*} p<0.05 * * p<0.01 * * * p<0.001$ (one-tailed tests).

Research model: Intention to return $\mathrm{R}^{2}=.667$; Consumers' overall attitude $\mathrm{R}^{2}=.671$; Consumer satisfaction $\mathrm{R}^{2}=.669$; Desires congruence $\mathrm{R}^{2}=.304$ 